International Journal of Current Advanced Research

ISSN: O: 2319-6475, ISSN: P: 2319 - 6505, Impact Factor: SJIF: 5.995

Available Online at www.journalijcar.org

Volume 6; Issue 3; March 2017; Page No. 2338-2340

DOI: http://dx.doi.org/10.24327/ijcar.2017. 2340.0004

Research Article

\title{
A STUDY TO ASSESS THE KNOWLEDGE OF HOUSE WIVES REGARDING HAZARDS OF PLASTIC AND ITS SAFE DISPOSAL IN AN URBAN COMMUNITY
}

\author{
*Dhanalakshmi, B \\ Department of community health nursing, Sree Balaji College of Nursing, Bharath University, \\ Chrompet, Chennai, Tamil Nadu, India
}

\begin{tabular}{l}
\hline A R T I C L E I N F O \\
\hline Article History: \\
Received $11^{\text {th }}$ December, 2016 \\
Received in revised form $7^{\text {th }}$ January, 2017 \\
Accepted $14^{\text {th }}$ February, 2017 \\
Published online $28^{\text {th }}$ March, 2017 \\
\end{tabular}

\begin{abstract}
A B S T R A C T
Plastic is everywhere in today's lifestyle. It's used for packaging, protecting, serving, and even disposing of all kinds of consumer goods. Through industrial revolution mass production of goods started and plastic seemed to be a cheaper and effective raw material. Today, every vital sector of the economy starting from agriculture to packaging, automobile, building construction, communication or InfoTech has been virtually revolutionised by the applications of plastics.
\end{abstract}

\section{Key words:}

Perturbed differential equations, delay, collocation method, Finite Element Method.

Copyright $\odot 2017$ Dhanalakshmi, B. This is an open access article distributed under the Creative Commons Attribution License, which permits unrestricted use, distribution, and reproduction in any medium, provided the original work is properly cited.

\section{INTRODUCTION}

The word "plastic" comes from the Greek word "plastikos" meaning "to form". Plastics is any of a group of synthetic or natural organic materials that may be shaped when soft and then hardened, including many types of resins, resinoids, polymers, cellulose derivatives, casein materials, and proteins: used in place of other materials, as glass, wood, and metals, in construction and decoration making many articles, as coatings, and, drawn into filaments, for weaving. The first man-made plastic was created by Alexander Parkes who publicly demonstrated it at the 1862 Great International Exhibition in London.

\section{Need For the Study}

India has witnessed a substantial growth in the consumption of plastics and an increased production of plastic waste. Polyolefin's account for the major share of $60 \%$ in the total plastics consumption in India. Packaging is the major plastics consuming sector, with $42 \%$ of the total consumption, followed by consumer products and the construction industry. On this basis, the total plastics consumption is projected to grow by a factor of six between 2000 and 2030. The consumption of various end products is combined with their corresponding lifetimes to calculate the total waste quantities.

\section{*Corresponding author: Dhanalakshmi, B}

Department of community health nursing, Sree Balaji College of Nursing, Bharath University, Chrompet, Chennai, Tamil Nadu, India
The weighted average lifetime of plastics products was calculated as 8 years. Forty-seven percent of the total plastics waste generated is currently recycled in India; this is much higher than the share of recycling in most of the other countries.

\section{Problem Statement}

"A study to assess the knowledge of house wives regarding hazards of plastic and its safe disposal in an urban community."

\section{Objectives}

Assess the knowledge of house wives regarding the hazards of plastic and its safe disposal.

\section{Operational definition}

Assess:-It refers to estimating of determine or evaluating the knowledge.

Knowledge:-It refers to the understanding of the individual regarding hazards of plastic and its safe disposal.

Plastic waste:-In this study plastic waste refers to the waste substance generated during the production and usage of plastic materials and its substances.

Hazards:-In this study hazard is a situation that poses a level of threat to life, health, property, or environment.

\section{Literature Related to Hazards of Plastic}

A study conducted on environmental and health hazard ranking and assessment of plastic polymers based on chemical composition, the environmental and health hazards of chemicals used in 55 thermoplastic and thermosetting 
polymers were identified and compiled. A hazard ranking model was developed for the hazard classes and categories .The polymers that ranked as most hazardous are made of monomers classified as mutagenic and/or carcinogenic. These belong to the polymer families of polyurethanes, poly acrylonitriles, polyvinyl chloride, epoxy resins, and styrenic copolymers. All have a large global annual production (1-37 million tonnes).

Use of this non biodegradable (according to recent studies, plastics can stay as long as 4500 years on earth) product is growing rapidly and the problem is what to do with plasticwaste. Studies have linked the improper disposal of plastic to problems as distant as breast cancer, reproductive problems in humans and animals, genital abnormalities and much more. If a ban is put on the use of plastics on emotional grounds, the real cost would be much higher, the inconvenience much more, the chances of damage or contamination much greater

Researchdesign: Non- experimental research design

Research Approach: Descriptive study.

Selection of Area: The area selected for the research study was Anagaputhur urban community which is situated 7KM away from our college. The municipal Town, Anagaputhur is described as a way of the Mangadu Karumari Amman temple. This area was selected because of its closeness to college and easy to get expected samples.

\section{Selection of Samples}

For the study, 30 samples were taken from Anagaputhur urban community, sampling technique adopted was convenient sampling method.

\section{Selection of Tool}

The tool for the study was a structured interview schedule.

\section{Data Collection Procedure}

The investigator explained the procedure of date collection to the samples. Their consent was obtained and the interview was conducted by the investigator to the sample individually.

\section{Plan for Dataanalysis}

The plan for data analysis is as follows:

Number and percentage to assess distribution of demographic data.

Number and percentage to assess distribution of level of knowledge regarding hazards of plastic and its safe disposal.

\section{ANALYSIS AND DISCUSSION DATA}

The subject of data collection deals with hazards of plastics and its safe disposal among house-wives in an urban community at Anagaputhur in Chennai .Tables and diagram were used for analysis the data on the basis of objectives of the study. Describe methods in number and percentage using tables and diagram.

The data tabulated under following materials:

Part 1: Numbers and percentage distribution of demographic data.

Part 2: Numbers and percentage distribution of level of knowledge.
Percentage Distribution of Level of Knowledge Regarding Hazards of Plastic and Its Safe Disposal

\begin{tabular}{cccc}
\hline SI.No & $\begin{array}{c}\text { Level of } \\
\text { Knowledge }\end{array}$ & $\begin{array}{c}\text { No of } \\
\text { people }\end{array}$ & $\begin{array}{c}\text { percen } \\
\text { tage }\end{array}$ \\
\hline 1 & inadequate & 3 & $10 \%$ \\
2 & Moderate & 12 & $40 \%$ \\
3 & adequate & 15 & $50 \%$ \\
\hline
\end{tabular}

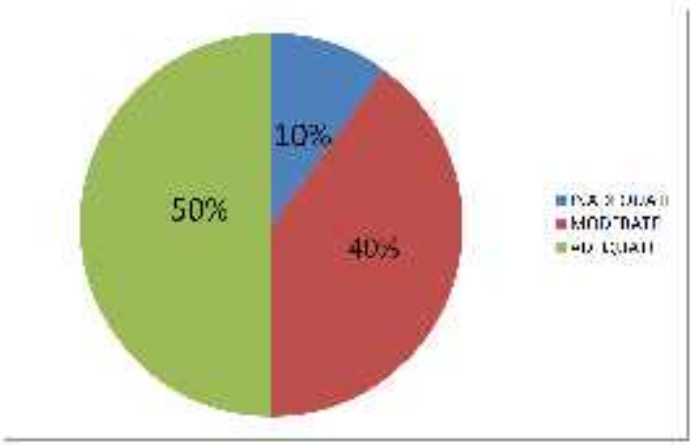

\section{CONCLUSION}

\section{The study findings revealed that}

Majority 2(7\%) of them aged between 18-22 years. 7(23\%) were between 23-27 years. Only 7(23\%) of people aged 2832 years. Majority $14(47 \%)$ of them were belongs to age group of above 32 years. Majority of them had only 1-6th standard $3(10 \%) .16(53 \%)$ of them had only education 7 th to12thstandard. Diploma $6(20 \%)$ and graduate $5(17 \%)$ education. $3612(40 \%)$ of them belongs to the income group of below 10 thousand per month. 11(36\%) of them belongs to income group of 10-20 thousand. 5(17\%) of them were belongs to income group of 20-30 thousand. $2(7 \%)$ of them getting Rs. above 30,000 thousand. 20 (67\%)of them belongs to Hindu family. $7(23 \%)$ were Christian and Muslim were $3(10 \%)$. Majority $4(13 \%)$ of them belongs to the open land method of plastic disposal. Majority 22(77\%) of them belongs to the dustbin method of plastic disposal. $3(10 \%)$ of them belongs to the burning method of plastic disposal. Only $3(10 \%)$ person had inadequate knowledge about hazards of plastic its safe disposal. 12(40\%) people had moderate knowledge.15 (50\%) people had adequate knowledge of hazards of plastic its safe disposal.

\section{References}

1. Elias, Hans-Georg" An Introduction toPlastics"4th edition. Wiley\&Weinheim Publishers; (2003); pno 121.

2. Andrady, Anthony." Plastics and the Environment" 6th edition. John Wiley \& Sons; (2003) ;pno 222.

3. Callan, Scott and Thomas.'Environmental Economics and Management" Environmental Health Journal; (2006) June4 (2):59.

4. Vipinm vasighte."Multitude ofplastic users". Indian Journal of Medical Sciences: 2010; Nov; 48 (8):46-55.

5. Kalpana Sunder "Plastics a Menace".The Indian Journal On Environmental Health.:2009;Jan37(3): 119-137.

6. O'Brine T, Thompson RC. "Effects of plastic wastes on Marine Environment". Marine Pollution Bulletin;Dec 2010; 60(12):2279-83. 
7. Huntley S." Public Health Implication of Household Solid Waste Management". The Internet Journal of Public Health:2005;mar;37(1-3): 119-137
8. Chaggu EJ, Kaseva ME.” Effects of open burning of Domestic wastes". Dar es salaam medical students' journal: 2010; January; 35(1): 170-171.

\section{Please cite this article in press as:}

Dhanalakshmi, B (2017), A study to assess the knowledge of house wives regarding hazards of plastic and its safe disposal in an urban community, International Journal of Current Advanced Research, 06(03), pp. 2338-2340.

http://dx.doi.org/10.24327/ijcar.2017. 2340.0004 